\title{
СТАН СОЦІАЛЬНО-ПСИХОЛОГІЧНОЇ АДАПТАЦІЇ/ДЕЗАДАПТАЦІЇ В СТРУКТУРІ ДЕПРЕСИВНИХ РОЗЛАДІВ РІЗНОГО ҐЕНЕЗУ У ЖІНОК З РІЗНИМ РІВНЕМ УРАЖЕНОСТІ ВНАСЛІДОК ДІї ДЕЗАДАПТУЮЧИХ ЧИННИКІВ МАКРОСОЦІАЛЬНОГО РІВНЯ
}

๑P. I. Ісаков

\section{ВДНЗ «Українська медична стоматологічна академія», Полтава}

РЕЗЮМЕ. Мета роботи - дослідження особливостей стану соціально-психологічної адаптації/дезадаптації (СПА/Д) у структурі депресивних розладів різного ґенезу у жінок з різним рівнем ураженості внаслідок дії дезадаптуючих чинників макросоціального рівня, для визначення в подальшому таргетних мішеней персоніфікації лікувально-реабілітаційних заходів для цього контингенту пацієнтів.

Матеріал і методи. В дослідження були включені 252 жінки з депресією різного ґенезу: 94 - психогенного (пролонгована депресивна реакція, обумовлена розладом адаптації), 83 - ендогенного (депресивний епізод; рекурентно депресивний розлад; біполярний афективний розлад, поточний епізод депресії) і 75 - органічного (органічні афективні розлади). Дослідження проводилося з використанням клініко-психопатологічного та психодіагностичного методів.

Результати. В результаті дослідження підтверджено вразливість жінок, хворих на депресивні розлади, до впливу чинників макросоціального стресу, та наявність прямої асоційованості між проявами макросоціальної дезадаптації (МакПД) й станом СПА/Д у структурі депресії у жінок, незалежно від їі ґенезу. Встановлено, що зі збільшенням тяжкості дезадаптивних ознак, унаслідок дії макросоціальних чинників, зменшується соціально-психологічна адаптивність та зростають вираженість й варіативність проявів соціально-психологічної дезадаптації як облігатного симптому депресивних розладів. Зі зростанням тяжкості МакПД відбувається зменшення показників прийняття себе і інших, внутрішнього контролю й домінування, на тлі збільшення неприйняття себе й інших, емоційного дискомфорту, зовнішнього контролю й керованості.

Висновок. Виявлені закономірності повинні враховуватися при розробці лікувально-реабілітаційних та профілактичних заходів при депресивних розладах у жінок.

КЛючОВІ СЛОВА: депресивні розлади; соціально-психологічна дезадаптація; макросоціальна дезадаптація; психогенна депресія; органічна депресія; ендогенна депресія.

Вступ. Соціально-психологічна адаптація особистості характеризується усвідомленням необхідності поступових змін відносин із соціальним середовищем через оволодіння новими способами поведінки, а також становленням нових пристосувальних механізмів, орієнтованих на гармонізацію стосунків особистості з середовищем [1-3]. Під соціально-психологічною дезадаптацією розуміють нездатність індивіда адекватно відповідати на пред'явлені до нього вимоги, засновані на очікуваннях, що відповідають його соціальному статусу і певному місцю в конкретній системі сформованих міжособистісних стосунків [4].

У клінічній психології і психіатрії соціально-психологічна дезадаптація виступає в декількох аспектах: і як симптом, і як діагностичний критерій оцінки тяжкості психопатологічного стану, і як тригерний або патопластичний чинник розвитку, насамперед, депресивних розладів [5, 6]. Справді, нестача здатності до соціально-психологічної адаптації у хворих на депресію $\epsilon$ і чинником ризику ії розвитку, і похідним у структурі її психопатологічних проявів $[7,8]$.

В останні роки інтерес дослідників до соціального контексту проблеми депресивних розладів має тенденцію до зростання [7-11]. у цьому аспекті проблема взаємовпливу між стресовим навантаженням, в умовах якого живе населення України останні роки, психосоціальноюдезадаптацією та депресивними розладами набуває особливої актуальності. Дія надсильних патологічних стресорів макросоціального рівня чинить дезорганізуючий вплив на соціальне функціонування окремих індивідуумів, викликаючи дестабілізацію психічного стану за рахунок формування перманентної нервово-психічної напруги через відсутність у них толерантності до невизначеності та наявності переживань щодо незахищеності перед глобальними загрозами гібридної війни [4].

Саме тому вивчення особливостей психосоціальної дезадаптації макросоціального рівня (МакПД) та ії впливу на прояви соціально-психологічної дезадаптації в структурі клінічної картини депресії $\epsilon$ важливим та актуальним.

Мета - дослідити особливості стану соціально-психологічної адаптації/дезадаптації (СПА/Д) у структурі депресивних розладів різного ґенезу у жінок з різним рівнем ураженості внаслідок дії дезадаптуючих чинників макросоціального рівня, для визначення в подальшому таргетних мішеней персоніфікації лікувально-реабілітаційних заходів для цього контингенту пацієнтів.

Матеріал і методи дослідження. На базі Полтавського обласного психоневрологічного дис- 
Огляди літератури, оригінальні дослідження, погляд на проблему, випадок з практики, короткі повідомлення пансеру й Полтавської обласної клінічної психіатричної лікарні імені О. Ф. Мальцева обстежено 252 жінки, хворих на депресію. Згідно з дизайном роботи, у дослідження були включені 94 жінки 3 депресивним розладом психогенного ґенезу (пролонгована депресивна реакція, зумовлена розладом адаптації, F43.21), 83 жінки з ендогенною депресією (депресивний епізод, F32.0, F32.1, F32.2, F32.3; рекурентний депресивний розлад, F33.0, F33.1, F33.2, F33.3; біполярний афективний розлад, поточний епізод депресії, F31.3, F31.4, F31.5) та 75 жінок із депресивним розладом органічного ґенезу (органічні афективні розлади, F06.3).

Особливості СПА/Д та змістовну оцінку її викривлення здійснювали з використанням «Методики соціально-психологічної адаптації К. Роджерса і Р. Даймонд» [12].

3 метою ідентифікації та виміру вираженості МакПД ми розробили оригінальну шкалу, що містила оцінку соціально-економічної та соціальноінформаційної складових МакПД, яка була апробована нами і довела свою валідність й ефективність [13]. Кожна сфера оцінювалася 10 питаннями. Мінімальна можлива оцінка за кожною сферою 10 балів (максимальна адаптація), максимальна 50 балів (максимальна дезадаптація).

Під соціально-економічною дезадаптацією ми розуміли порушення адаптації індивіда у соціальному середовищі під впливом майнових, економічних та фінансових чинників. Оцінка соціальноекономічної дезадаптації здійснювалась шляхом аналізу бальної відповіді пацієнток на наступних питань: Мені не вистачає грошей на поточні потреби; Я заробляю значно менше, ніж міг(могла) би; Я постійно турбуюся про гроші; За останній рік моя робота (бізнес) стала менш прибутковою; я втратив(ла) кар'єрні перспективи; Мені доводиться шукати додатковий заробіток; Я не можу дозволити собі заощаджувати; Мені доводиться позичати гроші (жити в кредит); Коли я думаю про гроші, я почуваюся нещасним(ою); Я не очікую покращення свого матеріального стану.

Під інформаційно-соціальною дезадаптацією розуміли порушення адаптації індивіда у соціальному середовищі під впливом інформаційних чинників. Оцінку інформаційно-соціальної дезадаптації здійснювали шляхом аналізу бальної відповіді пацієнток наступних питань: Інформація, яку я отримую, викликає у мене переважно негативні емоції; Я не довіряю інформації, яку одержую від ЗМІ та сторонніх людей; Я намагаюся не дивитися інформаційні програми і не відвідувати інформаційні сайти; Я ретельно відбираю інформацію для себе (дивлюся лише певні телеканали, відвідую лише окремі сайти, читаю тільки певні видання тощо); Після перегляду телевізора я відчуваю сум або тривогу; Вважаю, що у ЗМІ

надто багато негативної інформації; Мені доводилося конфліктувати з моїми родичами або близькими через зміст телевізійних програм, Інтернет-контенту тощо; Я відчуваю нестачу необхідної мені інформації; Нова інформація погіршує мою працездатність; Я надто емоційно реагую на нову інформацію.

Обстежені жінки за результатами оцінки ступеня МакПД з використанням розробленої нами шкали були поділені на дві групи. До першої групи увійшли 48 жінок, у яких показник МакПД не перевищував 19 балів, що відповідало відсутності ознак дезадаптації. До другої групи увійшли 204 жінки, у яких принаймні за однією зі шкал були виявлені показники понад 20 балів, що відповідає ознакам дезадаптації. При цьому показник за шкалою в межах 20-29 балів розцінювали як ознаки МакПД легкого ступеня, показник у межах 30-39 балів - як ознаки дезадаптації помірного ступеня, показник у 40 і більше балів - дезадаптації вираженого ступеня.

3 урахуванням поєднання ґенезу депресії та ступеня МакПД, було виділено 12 груп: 19 пацієнток з психогенною депресією та відсутністю ознак МакПД, 15 жінок з ендогенною депресією та відсутністю ознак МакПД, 14 жінок з органічною депресією та відсутністю МакПД, 50 жінок з психогенною депресією та МакПД легкого ступеня, 14 жінок з ендогенною депресією та МакПД легкого ступеня, 9 жінок з органічною депресією та МакПД легкого ступеня, 16 жінок з психогенною депресією та МакПД помірного ступеня, 37 жінок з ендогенною депресією та МакПД помірного ступеня, 18 жінок $з$ органічною депресією та МакПД помірного ступеня, 9 жінок з психогенною депресією та МакПД тяжкого ступеня, 17 жінок з ендогенною депресією та МакПД тяжкого ступеня, 34 жінки з органічною депресією та МакПД тяжкого ступеня.

Результати й обговорення. Нами було проаналізовано особливості СПА/Д у жінок, хворих на депресивні розлади, з урахуванням ступеня МакПД. Узагальнені дані щодо кількісних показників СПА/Д у жінок з депресивними розладами із наявністю та відсутністю ознак МакПД різного ступеня наведено у таблиці 1.

Як свідчать наведені дані, показники СПА/Д мали очевидну залежність від рівня МакПД. Показник адаптивності закономірно знижувався, а показник дезадаптивності - зростав зі збільшенням тяжкості МакПД. Показник правдивості зменшувався зі збільшенням тяжкості МакПД, апоказник брехливості мав складну тенденцію до збільшення при помірній МакПД і зменшення - при тяжкій. Показники прийняття себе і прийняття інших зменшувалися, а показники неприйняття себе і неприйняття інших збільшувалися зі зростанням тяжкості МакПД. Збільшення ознак МакПД супроводжувалося зменшенням емоційного комфорту і збільшенням емоційного 
Огляди літератури, оригінальні дослідження, погляд на проблему, випадок з практики, короткі повідомлення

Таблиця 1. Показники соціально-психологічної адаптації/дезадаптації у жінок, хворих на депресивні розлади, з різною вираженістю психосоціальної дезадаптації макросоціального рівня

\begin{tabular}{|c|c|c|c|c|c|c|c|c|}
\hline \multirow{2}{*}{ Показник } & \multicolumn{8}{|c|}{ Ступінь МакПД } \\
\hline & \multicolumn{2}{|c|}{ без ознак МакПД } & \multicolumn{2}{|c|}{ легка МакПд } & \multicolumn{2}{|c|}{ помірна МакПд } & \multicolumn{2}{|c|}{ тяжка МакПд } \\
\hline Адаптивність & \multicolumn{2}{|c|}{$67,42 \pm 14,03$} & \multicolumn{2}{|c|}{$45,47 \pm 9,46$} & \multicolumn{2}{|c|}{$39,56 \pm 9,35$} & \multicolumn{2}{|c|}{$27,33 \pm 11,21$} \\
\hline Дезадаптивність & \multicolumn{2}{|c|}{$144,00 \pm 19,23$} & \multicolumn{2}{|c|}{$168,55 \pm 15,63$} & \multicolumn{2}{|c|}{$178,37 \pm 13,26$} & \multicolumn{2}{|c|}{$185,00 \pm 5,85$} \\
\hline Брехливість ні & \multicolumn{2}{|c|}{$11,96 \pm 3,58$} & \multicolumn{2}{|c|}{$10,33 \pm 4,12$} & \multicolumn{2}{|c|}{$9,31 \pm 4,05$} & \multicolumn{2}{|c|}{$7,15 \pm 4,00$} \\
\hline Брехливість так & \multicolumn{2}{|c|}{$15,08 \pm 1,18$} & \multicolumn{2}{|c|}{$14,68 \pm 1,44$} & \multicolumn{2}{|c|}{$15,28 \pm 1,36$} & \multicolumn{2}{|c|}{$14,50 \pm 1,97$} \\
\hline Прийняття себе & $12,92 \pm 4$ & & & $97 \pm 3,47$ & $6,27 \pm 3$ & & & $35 \pm 1,99$ \\
\hline Неприйняття себе & $27,10 \pm 5$ & & & $55 \pm 2,70$ & $36,04 \pm 2$ & & & $15 \pm 0,99$ \\
\hline Прийняття інших & $17,06 \pm 3$ & & & $45 \pm 3,04$ & $10,32 \pm 3$ & & & $18 \pm 3,83$ \\
\hline Неприйняття інших & $28,29 \pm 3$ & & & $90 \pm 4,03$ & $32,14 \pm$ & & & $, 95 \pm 3,96$ \\
\hline Емоційний комфорт & $18,08 \pm 4$ & & & $90 \pm 3,29$ & $11,92 \pm 2$ & & & $30 \pm 4,18$ \\
\hline Емоційний дискомфорт & $28,58 \pm 4$ & & & $48 \pm 3,25$ & $35,52 \pm 2$ & & & $12 \pm 1,12$ \\
\hline Внутрішній контроль & $41,08 \pm 6$ & & & $66 \pm 7,31$ & $31,87 \pm 7$ & & & $97 \pm 9,01$ \\
\hline Зовнішній контроль & $36,35 \pm 6$ & & & $62 \pm 3,24$ & $42,62 \pm 3$ & & & $98 \pm 3,45$ \\
\hline Домінування & $4,96 \pm 2$ & & & $15 \pm 2,56$ & $2,87 \pm 2$ & & & $80 \pm 1,87$ \\
\hline Керованість & $26,58 \pm 2$ & & & $55 \pm 2,54$ & $30,45 \pm 1$ & & & $, 32 \pm 1,28$ \\
\hline Ескапізм & $20,33 \pm 2$ & & & $89 \pm 2,77$ & $21,46 \pm 2$ & & & $, 63 \pm 2,56$ \\
\hline Адаптація & $32,03 \pm 7$ & & & $35 \pm 4,82$ & $18,20 \pm 4$ & & & $65 \pm 4,70$ \\
\hline Самоприйняття & $32,51 \pm 7$ & & & $62 \pm 8,43$ & $26,55 \pm \varepsilon$ & & & $65 \pm 9,09$ \\
\hline Прийняття інших & $41,68 \pm 7$ & & & $00 \pm 7,10$ & $27,59 \pm 7$ & & & $91 \pm 9,22$ \\
\hline Емоційний комфорт & $38,71 \pm 8$ & & & $26 \pm 6,00$ & $25,05 \pm 4$ & & & $, 45 \pm 7,65$ \\
\hline Інтернальність & $44,86 \pm 7$ & & & $25 \pm 5,37$ & $34,37 \pm 5$ & & & $38 \pm 6,28$ \\
\hline Прагнення до домінування & $26,11 \pm 10$ & & & $58 \pm 9,97$ & $14,87 \pm 1$ & & & $27 \pm 9,12$ \\
\hline PiB & статисти & ग & $\mathrm{OCT}$ & біжносте & порівня & руп & & \\
\hline Показник & $\begin{array}{c}\text { Без ознак } \\
\text { МакПД } \\
\text { vs Легка } \\
\text { МакПД } \\
\end{array}$ & $\begin{array}{r}\text { Без } \\
\text { Мак } \\
\text { По } \\
\text { Ma }\end{array}$ & $\begin{array}{l}\text { знак } \\
\text { Д vs } \\
\text { рна } \\
\text { ПД } \\
\end{array}$ & $\begin{array}{c}\text { Без ознак } \\
\text { МакПД } \\
\text { vs Тяжка } \\
\text { МакПД } \\
\end{array}$ & $\begin{array}{c}\text { Легка } \\
\text { МакПД vs } \\
\text { Помірна } \\
\text { МакПД }\end{array}$ & $\begin{array}{r}\text { Л } \\
M a \\
\text { vs T } \\
M a\end{array}$ & & $\begin{array}{c}\text { Помірна } \\
\text { МакПД } \\
\text { vs Тяжка } \\
\text { МакПД } \\
\end{array}$ \\
\hline Адаптивність & $<0,01$ & & & $<0,01$ & $<0,01$ & & & $<0,01$ \\
\hline Дезадаптивність & $<0,01$ & & & $<0,01$ & $<0,01$ & & & $<0,05$ \\
\hline Брехливість ні & $<0,01$ & & & $<0,01$ & $>0,05$ & & & $<0,01$ \\
\hline Брехливість так & $>0,05$ & & & $>0,05$ & $<0,05$ & & & $<0,05$ \\
\hline Прийняття себе & $<0,01$ & & & $<0,01$ & $<0,01$ & & & $<0,01$ \\
\hline Неприйняття себе & $<0,01$ & & & $<0,01$ & $<0,01$ & & & $>0,05$ \\
\hline Прийняття інших & $<0,01$ & & & $<0,01$ & $<0,05$ & & & $<0,01$ \\
\hline Неприйняття інших & $<0,01$ & & & $<0,01$ & $>0,05$ & & & $>0,05$ \\
\hline Емоційний комфорт & $<0,01$ & & & $<0,01$ & $<0,05$ & & & $<0,01$ \\
\hline Емоційний дискомфорт & $<0,01$ & & & $<0,01$ & $<0,01$ & & & $<0,01$ \\
\hline Внутрішній контроль & $<0,01$ & & & $<0,01$ & $>0,05$ & & & $<0,01$ \\
\hline Зовнішній контроль & $<0,01$ & & & $<0,01$ & $<0,05$ & & & $>0,05$ \\
\hline Домінування & $>0,05$ & & & $<0,01$ & $<0,01$ & & & $<0,01$ \\
\hline Керованість & $<0,01$ & & & $<0,01$ & $>0,05$ & & & $>0,05$ \\
\hline Ескапізм & $>0,05$ & & & $>0,05$ & $<0,01$ & & & $>0,05$ \\
\hline Адаптація & $<0,01$ & & & $<0,01$ & $<0,01$ & & & $<0,01$ \\
\hline Самоприйняття & $<0,05$ & & & $<0,01$ & $<0,05$ & & & $<0,01$ \\
\hline Прийняття інших & $<0,01$ & & & $<0,01$ & $<0,05$ & & & $<0,01$ \\
\hline Емоційний комфорт & $<0,01$ & & & $<0,01$ & $<0,01$ & & & $<0,01$ \\
\hline Інтернальність & $<0,01$ & & & $<0,01$ & $<0,05$ & & & $<0,01$ \\
\hline Прагнення до домінування & $<0,05$ & & & $<0,01$ & $<0,01$ & & & $<0,01$ \\
\hline
\end{tabular}


Огляди літератури, оригінальні дослідження, погляд на проблему, випадок з практики, короткі повідомлення дискомфорту. Внутрішній контроль зменшувався, а зовнішній контроль - збільшувався по мірі зростання показників МакПД. Виявлено тенденцію до зменшення показників домінування і збільшення показників керованості зі зростанням ознак МакПД.

Прояви ескапізму збільшувалися при помірній МакПД і зменшувалися при легкій і помірній.

Середнє значення показника адаптивності у жінок з відсутністю ознак МакПД (рис. 1) склало $(67,42 \pm 14,03)$ балів, з ознаками МакПД легкого

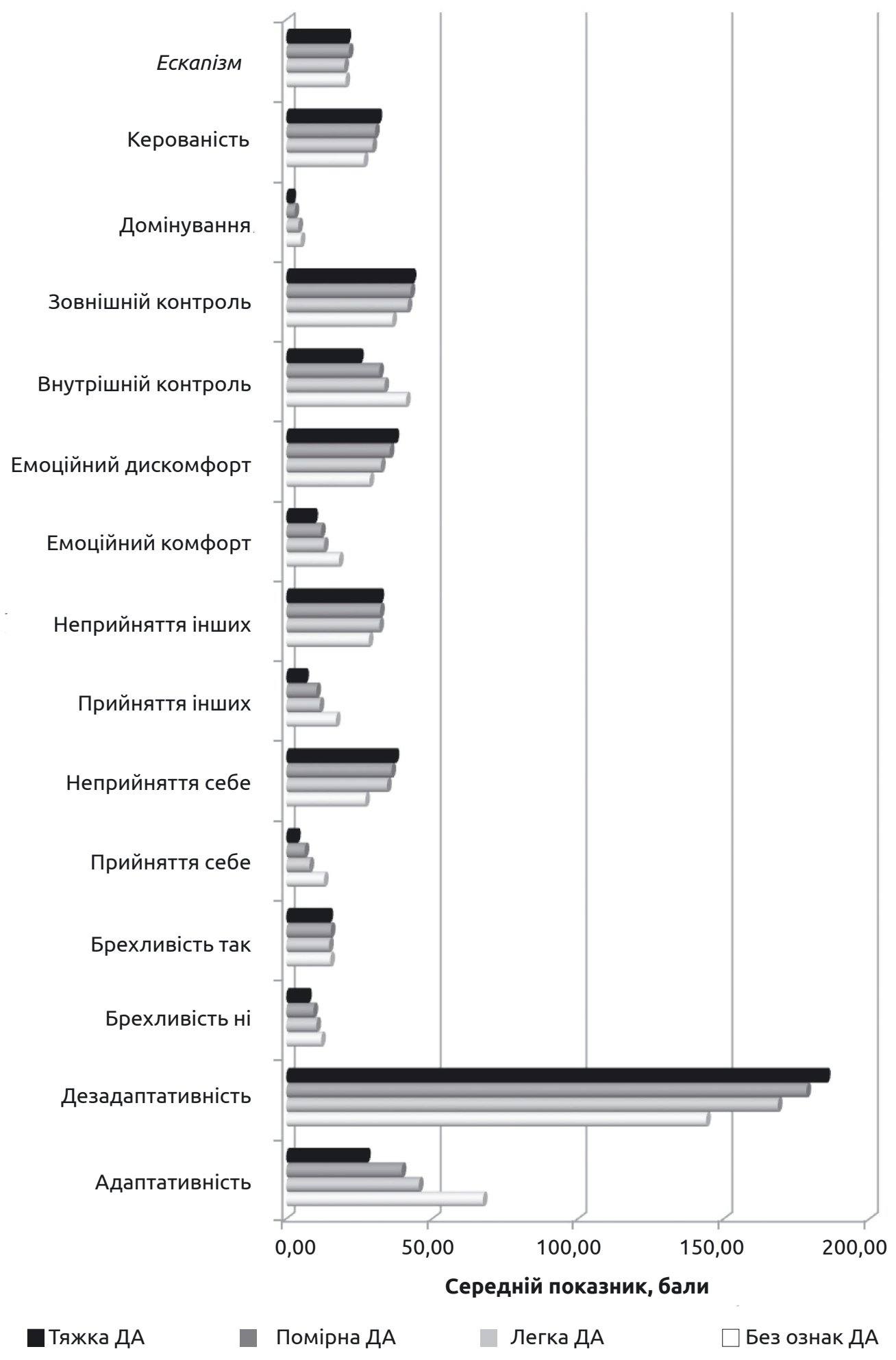

Керованість

Рис. 1. Середні показники соціально-психологічної адаптації/дезадаптації у жінок, хворих на депресивні розлади, з різними ступенями психосоціальної дезадаптації макросоціального рівня. 
Огляди літератури, оригінальні дослідження, погляд на проблему, випадок з практики, короткі повідомлення ступеня - $(45,47 \pm 9,46)$ балів, з ознаками МакПД помірного ступеню - $(39,56 \pm 9,35)$ балів, з ознаками МакПД важкого ступеню - $(27,33 \pm 11,21)$ балів; дезадаптивності - відповідно $(144,00 \pm 19,23)$ балів, $(168,55 \pm 15,63)$ балів, $(178,37 \pm 13,26)$ балів, $(185,00 \pm$ $5,85)$ балів; брехливості (ні) - відповідно $(11,96 \pm$ $3,58)$ балів, $(10,33 \pm 4,12)$ балів, $(9,31 \pm 4,05)$ балів, $(7,15 \pm 4,00)$ балів; брехливості (так) - відповідно $(15,08 \pm 1,18)$ балів, $(14,68 \pm 1,44)$ балів, $(15,28 \pm 1,36)$ балів, $(14,50 \pm 1,97)$ балів; прийняття себе - відповідно $(12,92 \pm 4,38)$ балів, $(7,97 \pm 3,47)$ балів, $(6,27 \pm 3,09)$ балів, $(3,35 \pm 1,99)$ балів; неприйняття себе - відповідно $(27,10 \pm 5,82)$ балів, $(34,55 \pm 2,70)$ балів, $(36,04 \pm$ $2,71)$ балів, $(37,15 \pm 0,99)$ балів; прийняття інших відповідно $(17,06 \pm 3,95)$ балів, $(11,45 \pm 3,04)$ балів, $(10,32 \pm 3,25)$ балів, $(6,18 \pm 3,83)$ балів; неприйняття інших - відповідно $(28,29 \pm 3,49)$ балів, $(31,90 \pm 4,03)$ балів, $(32,14 \pm 4,35)$ балів, $(31,95 \pm 3,96)$ балів; емоційного комфорту - відповідно $(18,08 \pm 4,27)$ балів, $(12,90 \pm 3,29)$ балів, $(11,92 \pm 2,51)$ балів, $(9,30 \pm 4,18) 6$ блів; емоційного дискомфорту - відповідно $(28,58 \pm$ $4,27)$ балів, $(32,48 \pm 3,25)$ балів, $(35,52 \pm 2,48)$ балів, $(37,12 \pm 1,12)$ балів; внутрішнього контролю-відповідно $(41,08 \pm 6,37)$ балів, $(33,66 \pm 7,31)$ балів, $(31,87 \pm$ $7,81)$ балів, $(24,97 \pm 9,01)$ балів; зовнішній контрольвідповідно $(36,35 \pm 6,12)$ балів, $(41,62 \pm 3,24)$ балів, $(42,62 \pm 3,85)$ балів, $(42,98 \pm 3,45)$ балів; домінування - відповідно $(4,96 \pm 2,43)$ балів, $(4,15 \pm 2,56)$ балів, $(2,87 \pm 2,03)$ балів, $(1,80 \pm 1,87)$ балів; керованості відповідно $(26,58 \pm 2,21)$ балів, $(29,55 \pm 2,54)$ балів, $(30,45 \pm 1,99)$ балів, $(31,32 \pm 1,28)$ балів; ескапізму-відповідно $(20,33 \pm 2,82)$ балів, $(19,89 \pm 2,77)$ балів, $(21,46 \pm 2,96)$ балів, $(20,63 \pm 2,56)$ балів.

Аналіз розбіжностей при порівнянні показників між різними групами за тяжкістю МакПД підтвердив їх значущість для більшості показників (крім брехливості, неприйняття інших та ескапізму, а також при порівнянні окремих груп за неприйняттям себе, внутрішнім і зовнішнім контролем, домінуванням і керованістю).

При аналізі інтегральних показників СПА/Д була виявлена чітка тенденція до зменшення показників адаптації, самоприйняття, прийняття інших, емоційного комфорту, інтернальності та прагнення до домінування паралельно зі зростанням рівня МакПД (рис. 2).

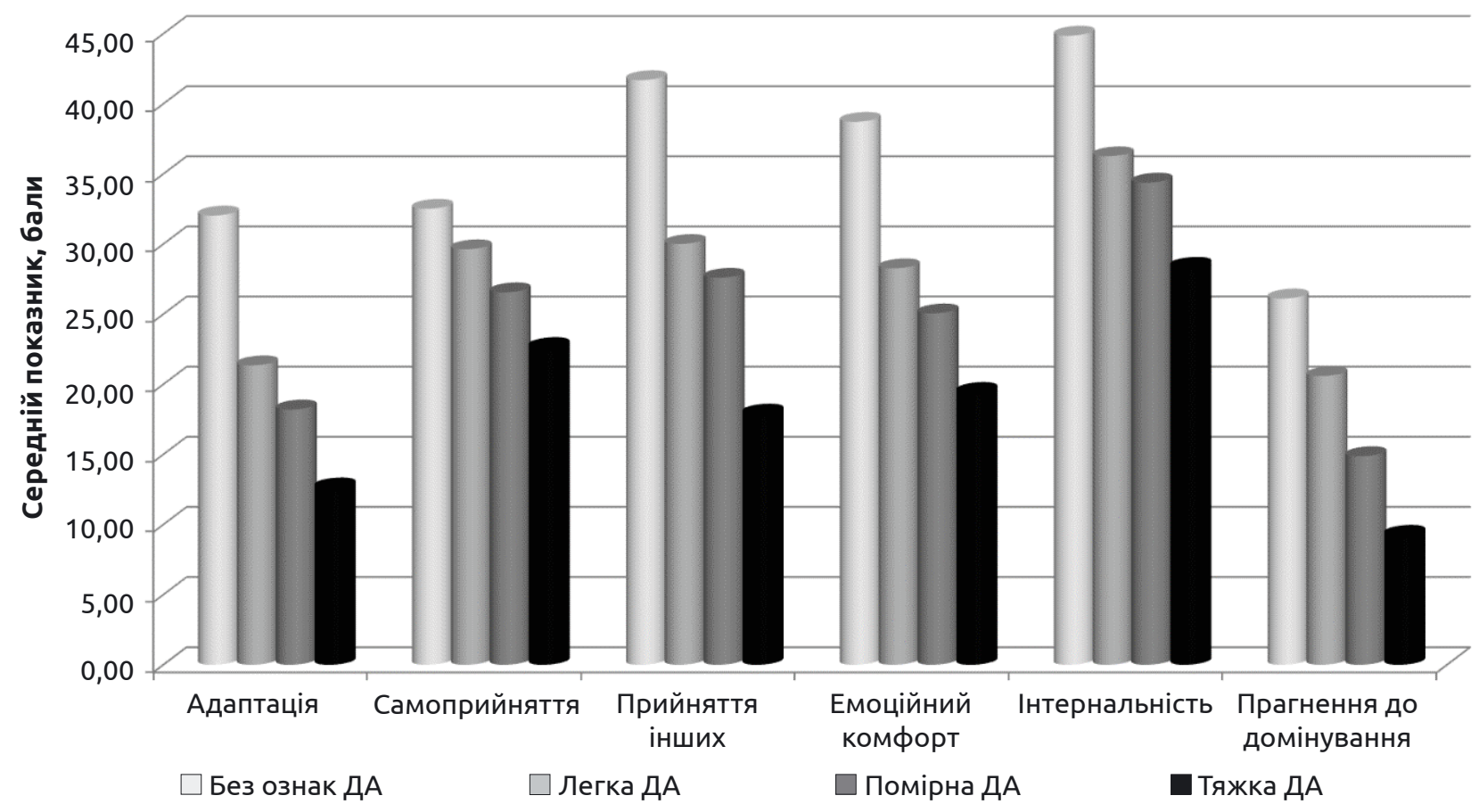

Рис. 2. Середні інтегральні показники соціально-психологічної адаптації/дезадаптації у жінок, хворих на депресивні розлади, з різними ступенями психосоціальної дезадаптації макросоціального рівня.

Середнє значення інтегрального показника

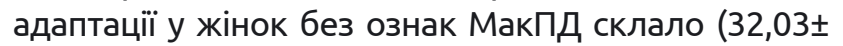
$7,04)$ балів, з ознаками легкої МакПД - $(21,35 \pm$ 4,82) балів, з ознаками помірної МакПД - $(18,20 \pm$

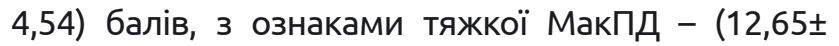

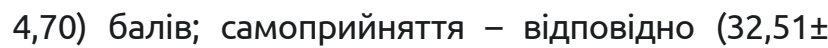
$7,37)$ балів, $(29,62 \pm 8,43)$ балів, $(26,55 \pm 8,13)$ балів, $(22,65 \pm 9,09)$ балів; прийняття інших - відповідно $(41,68 \pm 7,81)$ балів, $(30,00 \pm 7,10)$ балів, $(27,59 \pm 7,49)$ балів, $(17,91 \pm 9,22)$ балів; емоційного комфорту - від- 
Огляди літератури, оригінальні дослідження, погляд на проблему, випадок з практики, короткі повідомлення повідно $(38,71 \pm 8,63)$ балів, $(28,26 \pm 6,00)$ балів, $(25,05 \pm$ $4,82)$ балів, $(19,45 \pm 7,65)$ балів; інтернальності - відповідно $(44,86 \pm 7,07)$ балів, $(36,25 \pm 5,37)$ балів, $(34,37 \pm$ $5,90)$ балів, $(28,38 \pm 6,28)$ балів; прагнення до домінування - відповідно $(26,11 \pm 10,14)$ балів, $(20,58 \pm$ $9,97)$ балів, $(14,87 \pm 10,08)$ балів, $(9,27 \pm 9,12)$ балів.

При порівнянні між собою окремих груп з різним ступенем МакПД значущі ( $p<0,05$ і менше) розбіжності були виявлені для всіх можливих порівнянь для всіх інтегральних показників.

Висновки. В результаті дослідження підтверджено вразливість жінок, хворих на депресивні розлади, до впливу чинників макросоціального стресу, та наявність прямої асоційованості між проявами МакПД й станом СПА/Д у структурі депресії у жінок, незалежно від її ґенезу.

\section{ЛITЕРАТУРА}

1. Меерсон Ф. З. Адаптация, стресс и профилактика / Ф. З. Меерсон. - М. : Наука, 1981. - 276 с.

2. Налчаджан А. А. Социально-психологическая адаптация личности (формы и стратегии) / А. А. Налчаджан. - Ереван : Изд-во АН АрмССР, 1988. - 198 с.

3. Иванова А. И. Социально-психологическая адаптация: классификация и механизмы / А. И. Иванова // Вестник Университета. - 2014. - № 9. - С. 255-259.

4. Гапонов К. Д. Характеристика соціально-психологічної дезадаптації у хворих на алкогольну залежність з різним рівнем психосоціального стресу / К. Д. Гапонов // Scientific journal "Fundamentalis scientiam". 2019. - № 30. - P. 31-42.

5. Герасименко Л. О. Психосоціальна дезадаптація (сучасні концептуальні моделі) / Л. О. Герасименко // Український вісник психоневрології. - 2018. - Т. 26, вип. 1 (94). - С. 62-65.

6. Скрипніков А. М. Особливості континууму соціально-психологічної адаптації - дезадаптації у жінок з різними ґенезом депресії та вираженістю проблем у психосоціальному функціонуванні / А. М. Скрипніков, Р. І. Ісаков // Архів психіатрії. - 2019. - Т. 25, № 1. - С. 56-62.

7. Нециркулярні депресії : монографія / за ред. О. К. Напрєєнка. - К. : Софія-А, 2013. - 624 с.

\section{REFERENCES}

1. Meyerson, F.Z. (1981). Adaptatsiya, stress i profilaktika [Adaptation, stress and prevention]. Moscow: Nauka [in Russian].

2. Nalchadzhan, A.A. (1988). Sotsialno-psikhologicheskaya adaptatsiya lichnosti (formy i strategii) [Socio-psychological adaptation of personality (forms and strategies)]. Yerevan: Izd-vo AN ArmSSR [in Russian].

3. Ivanova, A.I. (2014). Sotsialno-psikhologicheskaya adaptatsiya: klassifikatsiya i mekhanizmy [Socio-psycho-

Встановлено, що зі збільшенням тяжкості дезадаптивних ознак унаслідок дії макросоціальних чинників, зменшується соціально-психологічна адаптивність та зростають вираженість і варіативність проявів соціально-психологічної дезадаптації як облігатного симптому депресивних розладів.

Зі зростанням тяжкості МакПД відбувається зменшення показників прийняття себе й інших, внутрішнього контролю й домінування, на тлі збільшення неприйняття себе та інших, емоційного дискомфорту, зовнішнього контролю й керованості.

Перспективи подальших досліджень. Виявлені закономірності повинні враховуватися при розробці лікувально-реабілітаційних та профілактичних заходів при депресивних розладах у жінок, що становить перспективу даного дослідження.
8. Рахман Л. В. Стан і структура соціального функціонування у пацієнтів із терапевтично-резистентними депресіями / Л. В. Рахман // Fundamental and Applied Researches in Practice of Leading Scientific Schools. 2015. - Issue 5 (11). - P. 110-121.

9. Марута Н. А. Восстановление социального функционирования - основная цель терапии депрессии / Н. А. Марута // Нейрonews. - 2013. - № 8 (53). - С. 16-20.

10. Волошин П. В. Основні напрямки наукових розробок в неврології, психіатрії та наркології в Україні / П. В. Волошин, Н. О. Марута // Український вісник психоневрології. - 2017. - Т. 25, вип. 1 (90). - С. 10-18.

11. Рахман Л. В. Концептуальні чинники розвитку та принципи лікування терапевтично резистентних депресій / Л. В. Рахман // Український вісник психоневрології. - 2016. - Т. 24, вип. 1 (86). - С. 104-110.

12. Фетискин Н. П. Социально-психологическая диагностика развития личности и малых групп / Н. П. Фетискин, В. В. Козлов, Г. М. Мануйлов. - М. : Изд-во Института Психотерапии, 2002. - С. 193-197.

13. Ісаков Р. І. Психосоціальна дезадаптація у жінок з депресивними розладами різного ґенезу: особливості діагностики, вираженості і структури / Р. І. Ісаков // Психіатрія, неврологія, медична психологія. - 2018. № 9. - С. 82-92. 
Огляди літератури, оригінальні дослідження, погляд на проблему, випадок з практики, короткі повідомлення

5. Herasymenko, L.O. (2018). Psykhosotsialna dezadaptatsiia (suchasni kontseptualni modeli) [Psychosocial maladaptation (modern conceptual models)]. Ukrainskyi visnyk psykhonevrolohii - Ukrainian Journal of Psychoneurology, 26, 1 (94), 62-65 [in Ukrainian].

6. Skrypnikov, A.M., \& Isakov, R.I. (2019). Osoblyvosti kontynuumu sotsialno-psykholohichnoi adaptatsii - dezadaptatsii u zhinok z riznymy henezom depresii ta vyrazhenistiu problem u psykhosotsialnomu funktsionuvanni [Features of the continuum of socio-psychological adaptation - maladaptation in women with different genesis of depression and severity of problems in psychosocial functioning]. Arkhiv psykhiatrii - Archive of Psychiatry, 25, 1, 5662 [in Ukrainian].

7. Napryeyenka, O.K. (2013). Netsyrkuliarni depresii (monohrafiia) [Non-circular depression (monograph)]. Kyiv: Sofiia-A [in Ukrainian].

8. Rakhman, L.V. (2015). Stan i struktura sotsialnoho funktsionuvannia u patsiientiv iz terapevtychno-rezystentnymy depresiiamy [The state and structure of social functioning in patients with treatment-resistant depression]. Fundamental and Applied Researches in Practice of Leading Scientific Schools, 5 (11), 110-121 [in Ukrainian].

9. Maruta, N.A. (2013). Vosstanovleniye sotsialnogo funktsionirovaniya - osnovnaya tsel terapii depressii [Restoration of social functioning - the main goal of the treatment of depression]. Neyronews, 8 (53), 16-20 [in Russian].

10. Voloshyn, P.V., \& Maruta, N.O. (2017). Osnovni napriamky naukovykh rozrobok v nevrolohii, psykhiatrii ta narkolohii v Ukraini [Basic directions of scientific developments in neurology, psychiatry and narcology in Ukraine]. Ukrainskyi visnyk psykhonevrolohii - Ukrainian Journal of Psychoneurology, 25, 1 (90), 10-18 [in Ukrainian].

11. Rakhman, L.V. (2016). Kontseptualni chynnyky rozvytku ta pryntsypy likuvannia terapevtychno rezystentnykh depresii [Conceptual factors of development and principles of treatment of therapeutically resistant depression]. Ukrainskyi visnyk psykhonevrolohii - Ukrainian Journal of Psychoneurology, 24, 1 (86), 104-110 [in Ukrainian].

12. Fetiskin, N.P., Kozlov, V.V., \& Manuylov, G.M. (2002). Sotsialno-psikhologicheskaya diagnostika razvitiya lichnosti i malykh grupp [Socio-psychological diagnosis of the development of personality and small groups]. Moscow: Izd-vo Instituta Psikhoterapii [in Russian].

13. Isakov, R.I. (2018). Psykhosotsialna dezadaptatsiia u zhinok z depresyvnymy rozladamy riznoho henezu: osoblyvosti diahnostyky, vyrazhenosti i struktury [Psychosocial maladaptation in women with depressive disorders of different genesis: features of diagnosis, severity and structure]. Psykhiatriia, nevrolohiia, medychna psykholohiia-Psychiatry, Neurology, Medical Psychology, 9, 82-92 [in Ukrainian].

\title{
СОСТОЯНИЕ СОЦИАЛЬНО-ПСИХОЛОГИЧЕСКОЙ АДАПТАЦИИ/ДЕЗАДАПТАЦИИ В СТРУКТУРЕ ДЕПРЕССИВНЫХ РАССТРОЙСТВ РАЗЛИЧНОГО ГЕНЕЗА У ЖЕНЩИН С РАЗНЫМ УРОВНЕМ ПОРАЖЕННОСТИ В РЕЗУЛЬТАТЕ ДЕЙСТВИЯ ДЕЗАДАПТИРУЮЩИХ ФАКТОРОВ МАКРОСОЦИАЛЬНОГО УРОВНЯ
}

○Р. И. Исаков

\author{
ВГУз «Украинская медицинская стоматологическая академия», Полтава
}

РЕЗЮМЕ. Цель - исследование особенностей состояния социально-психологической адаптации/дезадаптации (СПА/Д) в структуре депрессивных расстройств различного генеза у женщин с различным уровнем пораженности в результате действия дезадаптирующих факторов макросоциального уровня, для определения в дальнейшем таргетных мишеней персонификации лечебно-реабилитационных мероприятий для этого контингента пациентов.

Материал и методы. В исследование были включены 252 женщины с депрессией различного генеза: 94 психогенного (пролонгированная депрессивная реакция, обусловленная расстройством адаптации), 83 - эндогенного (депрессивный эпизод; рекуррентное депрессивное расстройство; биполярное аффективное расстройство, текущий эпизод депрессии) и 75 - органичного (органические аффективные расстройства). Исследование проводилось с использованием клинико-психопатологического и психодиагностического методов.

Результаты. В результате исследования подтверждена уязвимость женщин, больных депрессивными расстройствами, к воздействию факторов макросоциального стресса, и наличие прямой ассоциированности между проявлениями макросоциальной дезадаптации (МакПД) и состоянием СПА/Д в структуре депрессии у женщин, независимо от ее генеза. Установлено, что с увеличением тяжести дезадаптивных признаков вследствие действия макросоциальных факторов, уменьшается социально-психологическая адаптивность и растет выраженность и вариативность проявлений социально-психологической дезадаптации, как облигатного симптома депрессивных расстройств. С ростом тяжести МакПД происходит уменьшение показателей принятия себя и других, внутреннего контроля и доминирования, на фоне увеличения неприятия себя и других, эмоционального дискомфорта, внешнего контроля и ведомости.

Вывод. Выявленные закономерности должны учитываться при разработке лечебно-реабилитационных и профилактических мероприятий при депрессивных расстройствах у женщин.

КЛЮчЕВЫЕ СЛОВА: депрессивные расстройства; социально-психологическая дезадаптация; макросоциальная дезадаптация; психогенная депрессия; органическая депрессия; эндогенная депрессия. 
Огляди літератури, оригінальні дослідження, погляд на проблему, випадок з практики, короткі повідомлення

\section{THE SOCIO-PSYCHOLOGICAL ADJUSTMENT/MALADJUSTMENT IN THE STRUCTURE OF DEPRESSIVE DISORDERS OF DIFFERENT GENESIS IN WOMEN WITH DIFFERENT LEVELS OF AFFLICTION DUE TO THE ACTION OF MACROSOCIAL LEVEL OF MALADAPTIVE FACTORS}

OR. I. Isakov

\section{Ukrainian Medical Dental Academy, Poltava}

SUMMARY. The aim - to study the features of the state of socio-psychological adaptation/disadaptation (SPA/D) in the structure of depressive disorders of different genesis in women with different levels of affliction due to the action of macrosocial level maladaptive factors, to determine further targeted targets for personification of this personification. patients.

Materials and Methods. The study included 252 women with depression of different genesis: 94 - psychogenic (prolonged depressive response caused by adaptation disorder), 83 - endogenous (depressive episode; recurrently depressive disorder; bipolar affective disorder, current episode of depression) and 75 - organically depressed and 75 disorder). The study was conducted using clinical psychopathological and psychodiagnostic methods.

Results. The study confirmed the vulnerability of women suffering from depressive disorders to the effects of macrosocial stress factors, and the existence of a direct association between the manifestations of macrosocial maladaptation (MacPM) and the state of SPA/D in the structure of depression in women, regardless of its genesis. It has been established that with increasing severity of maladaptive traits due to the action of macrosocial factors, sociopsychological adaptability decreases, and the manifestation and variability of manifestations of social-psychological maladaptation, as a obligatory symptom of depressive disorders, increases. With the increasing severity of the MacPD, there is a decrease in the indicators of acceptance of oneself and others, internal control and domination, against the background of increasing rejection of self and others, emotional discomfort, external control and awareness.

Conclusions. The identified patterns should be taken into account in the development of treatment and rehabilitation and preventive measures for depressive disorders in women.

KEY WORDS: depressive disorders; social and psychological maladaptation; macrosocial maladaptation; psychogenic depression; organic depression; endogenous depression. 